\title{
Enforcement of the Code of Ethics of the Chief of Police of the Republic of Indonesia Who Commits Criminal Decency
}

\author{
Heru Waluyo ${ }^{1}$, Evita Isretno Israhadi ${ }^{2}$ \\ Student Program Doctor of Law Borobudur University, Jl. Pemuda, RT.1/RW.3, \\ Rawamangun, Kec. Pulo Gadung, DKI Jakarta 13220, Indonesia ${ }^{1}$, University of Borobudur, Jl. \\ Pemuda, RT.1/RW.3, Rawamangun, Kec. Pulo Gadung, DKI Jakarta 13220, Indonesia ${ }^{2}$ \\ \{herwa199@gmail.com¹, evita_isretno@borobudur.ac.id²\}
}

\begin{abstract}
Violation of Decency for the Police members can't be avoided in his life as a social being. However, members of the National Police every behaviour are bound or subject to the Code of Conduct of the Police Profession, but still found members of the Police committed violations, which is a violation of Decency. This research is empirical research with a sociological juridical approach method. This article will explain the handling of police officers who violate the Crime of Decency. Violations of Decency of members of the National Police can be processed through the session of the Code of Ethics and the General Judicial Council and after first proven criminal violations through the general judicial process up to the decision of the court that has a permanent legal force if the contravention of Decency is a threat of punishment of 4 (four) years, it can be done PTDH process (Dismissal with disrespect).
\end{abstract}

Keywords: Code of Conduct; Police department; criminal offences; Decency

\section{Introduction}

The success of the implementation of police duties in maintaining security and public order, enforcing the law, protecting, and protecting the community in addition to being determined by the quality of knowledge and technical skills of the Police to realize the commendable behaviour of every member of the Police, is always required to animate and animate the ethics of the police profession which is the crystallization of tribrata values and prasetya chess based on and imbued by Pancasila.

Each organization must have a pattern of discipline enforcement for every employee, namely by creating rules and regulations that must be implemented by employees, creating and sanctioning for disciplinary violators through continuous training, coaching through this training can be in the form of physical activity by providing training to the Police and mental training, namely utilizing religious lectures and psychology.

The behaviour of members of the National Police who commit violations can affect their performance as members of the National Police as the theory of legal effectiveness put forward by Soerjono Soekanto, relevant to the idea put forward by Romli Atmasasmita, 
namely that the factors that hinder the force of law enforcement not only lie in the mental attitude of law enforcement officers (judges, prosecutors, Police and law enforcement) but also lies in the socialization factors of law that are often overlooked. According to Soekanto, effectiveness is the extent to which a group can achieve its goals. The law can be said to be effective if there is a positive legal impact. At that time, the law achieves its objectives in guiding or changing human behaviour to become legal behaviour.

The Police reform movement has been started on April 1, 1999, which is marking by the separation of the National Police from ABRI is the mandate of the people for the National Police back to its identity as civilian Police that sided with the citizens as stakeholders, not on the other side of the ruler. Reform on the cultural aspect remains a paramount concern in the grand strategy agendas of police reform and reforms on structural and instrumental elements.

Each organization must have a pattern of discipline enforcement for each employee, namely by creating rules and regulations that must be implemented by employees, creating and sanctioning for disciplinary violators through continuous corrective training, coaching through this training can be in the form of physical activity by providing training to the Police and mental-spiritual training that is employing religious lectures and psychology.

The behaviour of members of the National Police who commit violations can affect their performance as members of the National Police as the theory of legal effectiveness put forward by Soekanto, relevant to the idea put forward by Atmasasmita, namely that the factors that hinder the force of law enforcement not only lie in the mental attitude of law enforcement officers (judges, prosecutors, Police and law enforcement) but also lies in the socialization factors of law that are often overlooked.

The rapid advancement of information technology has an impact on polarization, new rationalization in the scope of modern crime so that it affects the professionalism of the National Police in carrying out its essential duties as mandated by Law No. 2 of 2002, with the impact that members of the National Police are required to improve their quality through the educational process that uses information technology.

The Session of the Police Professional Code of Ethics is one of the Provos' duties to prepare the file and submit it to Ankum for the National Police members. They violate personality ethics, state ethics and ethics in relations to the community. The Police Code of Conduct in the future, referred to as the Commission of a container established within the National Police, is tasked with examining and investigating violations of the Police Professional Code of Conduct as well as violations of Article 12, Article 13 and Article 14 of Government Regulation No. 1 of 2003 concerning Dismissal of Members of the National Police and Article 13 of Government Regulation No. 2 of 2003 concerning Discipline Regulations of Police Members.

Government Regulation No. 1 of 2003 concerning the dismissal of members of the National Police of the Republic of Indonesia, Government Regulation No. 2 of 2003 concerning the discipline regulations of members of the National Police of the Republic of Indonesia (Polri Disciplinary Regulation), Government Regulation No. 3 of 2003 concerning the institutional, technical implementation of the general judiciary for members of the state police of the Republic of Indonesia, and Government Regulation No. 23 of 2007 concerning the jurisdiction of the State Police of the Republic of Indonesia. Presidential Regulation No. 52 of 2010 concerning The Organization and Working Procedure of the Republic of Indonesia's National Police. Regulation of the National Police No. 14 of 2011 concerning the Code of Ethics of the National Police of the Republic of Indonesia (Code of Conduct of the National Police). 
There are several cases of dismissal for members of the National Police of the Republic of Indonesia who committed violations/crimes/codes of conduct with disrespect from the police service, among others: Krisman Adi Rumapea, Rijki Afandi and Argan Roy Gultom violated / code of ethics Article 14 paragraph (1) letter a PP R.I No. 1 the Year 2003 Concerning Dismissal of Members of the National Police of the Republic of Indonesia.

\section{Methodology}

This research uses a type of normative juridical research (Soemitro, 1983), both in the form of rules and legal theories, in addition to studying the rules of law that apply in the Police and society, so that it is put forward a legal principle in the form of dogma or legal doctrines that are theoretically scientific and can be used to analyze the problems discussed (Soerjono and Sri Mahudji, 1995), which can answer questions under the subject matter.

Research conducted using descriptive-analytical approach methods, namely exposing and analyzing data systematically to provide data as relevant as possible about humans, circumstances and other symptoms. Descriptive means that the author wants to describe and deliver data as thoroughly as possible, systematically and thoroughly. The analysis contains meaning, grouping, combining and comparing aspects related to problems in theory and practice.

\section{Discussion}

\subsection{Legal Regulations against Polri who do not Enter the Service}

According to Perkap No. 14 of 2011 concerning The Code of Professional Ethics, Article 13 paragraph (1) states: "Members of the National Police of the Republic of Indonesia may be dishonourably discharged from the Service of the State Police of the Republic of Indonesia for violating the oaths/promises of members of the State Police of the Republic of Indonesia, oaths/appointments, and The Code of Professional Ethics of the State Police of the Republic of Indonesia". Furthermore, article 1 of Law No. 2 of 2002 reads: the police force is all matters relating to the Police's functions and institutions under the laws and regulations.

Law No. 2 of 2002 concerning the Police of the Republic of Indonesia and Government Regulation No. 3 of 2002 concerning the Institutional Technical Implementation of Public Justice for Members of the National Police. Related to disciplinary violations through disciplinary hearings, based on government Regulation No. 2 of 2003 concerning Police Members' Disciplinary Regulations.

The rule of law against POLRI leaves the duty of service unlawfully for (thirty) consecutive days. Any violation of the Code of Professional Ethics shall be subject to moral sanctions submitted in the form of a decision of the Police Code of Conduct in writing to the examiner (Article 11 paragraph 3 and Article 12 paragraph 1 of the Police Professional Code of Conduct). The form of the moral sanction imposed can be a statement of the verdict that states unproven or a statement of the judgment that says that the examiner has violated the Code of Professional Ethics of the National Police. As stipulated in Article 11 paragraph 2 (a, $\mathrm{b}$ and $\mathrm{c}$ ), a moral sanction is a form of moral sanction that is absolute and binding. This means that the moral sanction is subject to sanctions easing up to the heaviest level of sanctions 
following the violations of the examined behaviour that can be proven in the Commission Session.

The Regulation of Police Discipline regulation with the Government regulation has been adapted to the demands of duties and authorities and responsibilities of members of the National Police of the Republic of Indonesia, which is civil. Besides, the formulation of police disciplinary regulations is adjusted to the context of the development of law and state regulations and the community's aspirations following the demands of the times. Members of the Police will become civilian police officers and serve all people from various social strata and ranks in the community. Every Police Officer must remember that no qualification is indispensable to a police officer other than perfectly emotional or anger control, not to put into the heart any form of a deed, including the very slightest degree of utterance or threat that may be made to him or her.

Disciplinary rules are also loaded about sanctions imposed on members of the Police if they violate the prohibition or regulation. The disciplinary regulations are to create police members in a working atmosphere filled with conflict, conflict and uncertainty, and foster a new character and culture of the Police under the demands of reform as civil Police. The Police's discipline rules are subject to the procedure of examination, disciplinary punishment, and filing objections if the police member who is sentenced to the discipline felt objected to the sentence convicted to him. The purpose of disciplinary punishment is to improve and educate the Police who commit disciplinary violations to change for the better.

Article 3 of Government Regulation No. 2 of 2003 regulates the obligations, prohibitions and sanctions for members of the Police, stating: In the framework of state life and society members of the Indonesian Republik State police must: a. Loyal and wholly obedient to Pancasila, the Constitution of the Republic of Indonesia year 1945, the state and the government. B. Put the state's interests above the interests of individuals or groups and avoid anything that harms the state's interests. c. Uphold the honour and dignity of the State, government, and Police of the Republic of Indonesia; d. Deviate state secrets and position secrets properly; E. Respect between religions; F. Upholding human rights; G. Comply with generally applicable laws and regulations; H. Report to your employer if you know of anything that could harm the state or government; i. Behave and behave in manners towards the community and $\mathrm{j}$. She was dressed neatly and appropriately.

Article 4 PP No. 2 of 2003 regulates the obligations that must be carried out by members of the Police in the implementation of duties. The responsibilities are as follows: a. Provide the best protection, protection, and service to the community; B. Pay attention and resolve the best possible community reports and or complaints; c. Comply with the oath or promise of members of the National Police of the Republic of Indonesia and commitment or appointment of office based on the prevailing laws and regulations; $d$. Carry out the task as best as possible with awareness and sense of responsibility; E. Maintaining and improving the integrity, cohesion, unity and unity of the Indonesian Police; F. Comply with all applicable laws and regulations and regulations; G. Act and be firm and be just and wise to its actions; H. Guiding subordinates in carrying out tasks; i. Set a good example of his associates; A. Encourage the spirit of his assistants to improve work performance; K. Provide opportunities for his subordinates to develop careers; 1 . Obey the valid order of the competent superior; $\mathrm{m}$. Comply with the provisions of working hours; N. Using and maintaining the service's property as best as possible; O. Creating and maintaining an excellent working atmosphere.

The formulation in Article 4 of the Government regulation contains the legal basis for the organizers of preventive police functions and stipulated in Article 14 paragraph (1) letter I of Law No. 2 of 2002. If violated, the ban was made because it can degrade the honor and dignity 
of the State, government, and Police. Members of the Police are prohibited from conducting practical political activities because it is feared that it can lead to disintegration in the police environment. The participation of police members in certain schools is also considered to threaten the nation's unity and unity. Another prohibited act is to act as an intermediary or broker for the ruler or group to get a job (project) or order for personal benefit. Members of the Police are also prohibited from owning shares/capital whose business activities in the scope of his power because this will give rise to the practice of KKN, including forbidden to become a realtor of the case.

According to Article 11, if the person concerned violates the prohibition to a. own, sell, buy, mortgage, rent, or lend moving or immovable goods, documents or securities belonging to the state, unlawfully; $b$. conduct joint activities with superiors, associates, subordinates, or others inside or outside the work environment for personal gain, class, or other parties directly or indirectly detrimental to the state; c. act arbitrarily towards his subordinates; d. take action or not take a move that may hinder or complicate one of the parties served, resulting in losses to the performed; e. blocking the ministry's task's running.

\subsection{Factors Causing Violation of the Police Code of Ethics}

According to Soerjono Soekanto, law enforcement in the professional code of conduct is influenced by five factors: (Soekanto, 1983): 1) Legal or statutory factors; 20 Factors of law enforcement officials, namely those involved in the process of making and applying the law, relating to mentality issues; 3) Factors of facilities or facilities that support the law enforcement process; 4) Community factors, i.e. the social environment in which the law applies or is applied; relates to awareness and compliance of laws reflecting in community behaviour; and 5) Cultural factors, namely the work, copyright and taste based on the human initiative in the association of life.

As law enforcement in general in the application of the Code of Professional Ethics of the Police is also inseparable from the five factors that are closely related because it is the essence of law enforcement itself. Starting from the legal aspects, law enforcement factors, community factors in this case, members of the National Police as the object of law enforcement Code of Professional Ethics polri and cultural factors in the organization of the National Police and the community in general, and to know the extent of these five factors as a benchmark for the effectiveness of law enforcement Code of Professional Ethics Polri.

Some of these factors include:

\section{a) Legal Factors}

The National Police have anticipated police irregularities in Indonesia through various instruments of police personnel supervision. First, through the existence of legal mechanisms in the form of regulations. In addition to criminal offences that are generally regulated in the Criminal Code, in carrying out its personnel's supervisory function, the National Police has two main foundations: disciplinary regulations and professional codes of conduct. The disciplinary rules of members of the National Police are regulated through PP No. 2 of 2003. The second basis is the professional code of ethics stipulated in The National Police Regulation No. 14 of 2011. The problem is that it is challenging to separate firmly between the various internal rules. There is always a grey colour, and there is always a light side and a dark side. There will always be overlap between the various regulations. Another problem besides the above problem is the frequent regulation that governs the Code of Professional 
Conduct of the Police. As is known before the enactment of Police Regulation No. 14 of 2011 concerning the Code of Professional Ethics of the Police, there have been two Police Regulations governing the same thing, namely the Decree of the Police Chief No. Pol: KEP/32/VII/2003 and The Police Chief Regulation No. 7 of 2006. That is, the rules on the Code of Professional Ethics of the Police have twice changed. Also, the new Police Professional Code of Conduct regulation is not available adequate explanation even no explanation at all. As a result of the multi-interpretation rule, each party will have different interpretations to open the opportunity for manipulation in law enforcement, ultimately creating legal uncertainty.

\section{b) Law Enforcement Factors}

The law enforcement officers referred to herein are the Police's functions that will enforce the Police Professional Code of Conduct in this case, Bidpropam. As it is known, the number of police personnel is not balanced with the number and complexity of police personnel problems. The number of Police personnel is only 126 personnel. The police jurisdiction is a different obstacle for Bidpropam Polri in implementing the police profession's code of ethics. Therefore, the real obstacle faced is the lack of capacity of police personnel members to cover the entire area that is the responsibility of the National Police.

Another problem besides the above problem is that the Head of the National Police Organization Unit as Ankum at all levels has not been able to sanction members of the Police who committed violations through the hearing of the Police Code of Conduct Commission so that the expectation of the slightest infraction followed up with corrective actions or sanctions is not achieved. The cause is still among the unit leaders as Ankum. They have not entirely given attention to the implementation of law enforcement duties of the Police Professional Code of Conduct, including officers Wabprof Subfield.

\section{Conclusion}

The Police have taken precautions so as not to occur personality irregularities or violations by conducting mental guidance that is routinely carried out on Thursdays and daily directives or suppressive suppressors by the leaders hoping that members of the Police comply with the law. Members of the National Police must know and understand the police profession's code of ethics and implement it. Every member of the National Police must have a high determination and commitment to practice the conduct code. If the code of ethics is adhered to in all forms of life, then the hope for creating professional police people and institutions and loved by the people can be carried out. The good of the police institutions depends on high moral integrity in every member of the National Police.

Violation of criminal Decency for members of the National Police in the legal process through the General Justice after a court ruling that has the force of law continues to be carried out internal policy process, namely Preoses Code of Ethics to get sanctions from the institution of the police institution. So if a member of the National Police commits a crime of Decency, he gets criminal sanctions and code of conduct sanctions. 


\section{References}

[1] Ardita, Mikho. 2020. "Tanggung Jawab Negara Terhadap Jaminan Kesehatan Dalam Perspektif Hak Asasi Manusia.” Jurnal HAM 11(2): 319-33.

[2] Ibnu Suka, Gunarto, U. M. (2018). Peran dan Tanggung Jawab Polri Sebagai Penegak Hukum dalam Melaksanakan Restorative Justive untuk Keadilan dan Kemanfaatan Masyarakat. Jurnal Hukum Khaira Ummah, 13(1), 111-118.

[3] Rendra, G. (2019). Kewenangan Penuntut Umum Dalam Penyidikan Perkara Pencegahan Pemberantasan Perusakan Hutan (P3H). Jurnal Yuridis, 6(2), 157. https://doi.org/10.35586/jyur.v6i2.1076

[4] Supriyanto, E. E. (2021). Konsep Pembangunan dan Pengembangan Ekowisata. In Pengantar Manajemen Potensi Desa: Aku Yakin Desaku Punya Sejuta Potensi (Vol. 1, Issue 1 ,

pp.

116-129). http://dx.doi.org/10.1016/j.cirp.2016.06.001\%0Ahttp://dx.doi.org/10.1016/j.powtec.20 16.12.055\%0Ahttps://doi.org/10.1016/j.ijfatigue.2019.02.006\%0Ahttps://doi.org/10.10 16/j.matlet.2019.04.024\%0Ahttps://doi.org/10.1016/j.matlet.2019.127252\%0Ahttp://dx .doi.o

[5] Supriyanto, E. E. (2021). Politik Kebijakan Ketahanan Pangan Indonesia Pasca Pandemi Covid-19. In Pertanian Dalam Ketahanan Pangan Selama dan Sesudah Covid-19 (Vol. 1, Issue 1, pp. 33-43). Penerbit Yayasan Guna Widya Paramesthi. 